\title{
Saving Dupinga Watershed in Gabaldon, Nueva Ecija Philippines: Insights from Community Based Forest Management Model
}

\author{
Arneil G. Gabriel1 ${ }^{*}$, Eric G. Claudio², Feliciano A. Bolisay ${ }^{1}$ \\ ${ }^{1}$ Department of Public Administration, Nueva Ecija University of Science and Technology, Cabanatuan City, Philippines \\ ${ }^{2}$ Department of Environmental Science and Management \& Office for International Linkages, Nueva Ecija University of Science \\ and Technology, Cabanatuan City, Philippines \\ Email: *opats14@yahoo.com
}

How to cite this paper: Gabriel, A.G., Claudio, E.G. and Bolisay, F.A. (2017) Saving Dupinga Watershed in Gabaldon, $\mathrm{Nu}$ eva Ecija Philippines: Insights from Community Based Forest Management Model. Open Journal of Ecology, 7, 140-157. https://doi.org/10.4236/oje.2017.72011

Received: February 2, 2017

Accepted: February 21, 2017

Published: February 24, 2017

Copyright $\odot 2017$ by authors and Scientific Research Publishing Inc. This work is licensed under the Creative Commons Attribution International License (CC BY 4.0). http://creativecommons.org/licenses/by/4.0/

\begin{abstract}
The world is losing its forest. The study described the multi-sectoral initiatives done to protect the Dupinga watershed. By using Community Based Forest Management (CBFM) as theoretical framework and analytic descriptive method of research, issues and concerns related to watershed protection are discussed. The study argued that the multi-sectoral collaboration of the Local Government Unit of Gabaldon, the Department of Environment and Natural Resources (DENR), Peoples Organizations, Non Government Organizations (NGO) and Community Organization is a CBFM in progress. Alternative source of income and community tourism may strengthen and sustain the multi-stake-holders collaboration existing in the area while capacity building program for community participation and forest management may provide insights for a sustainable watershed protection and management.
\end{abstract}

\section{Keywords}

Sustainable Development, Case Study Community Based Forest Management, Dupinga Watershed in the Philippines

\section{Introduction}

\subsection{Importance of Forest Eco-System and the Need for Reforestation}

The world is losing its forest. The forest ecosystem is continuously degraded as a result of the prevailing anthropogenic perspective of individuals towards forest 
resources. The forest is not only home to millions of animal species but also habitat for peculiar flowers and plants. Experts agreed that the world is "losing almost 80,000 acres of tropical rainforest daily and endangering 135 plant, animal and insect species every day" [1]. According to Cruz and Acay, there is a dismal ecological imbalance in the Philippine forest condition [2]. Forest denudation and degradation are at the rate of 200,000.00 hectares per annum equivalent to 25 hectares per hour [3]. Available data also showed that in 1995, there are only 5 million hectares of forest lands left with only 800,000 hectares considered as old growth forest. The Philippines is a host to more than 9250 plant species one third of which is now in danger of extinction [4].

Forest ecosystem provides support to other life giving natural and social environments. It is a host to environmental services that are not ordinarily translated in terms of market value. They are the indirect and direct benefits society derived from the environment. For instance, trees are filtering carbon dioxide that causes harm to health of human persons. The forest ensures economic survival of million communities depending on it for livelihood [5] [6]. It further ensures continues supply of high quality water necessity to innumerable communities and agricultural farm lands. Indeed, forest ecosystem is important to the communities depending on it for survival. Recent data showed that "forest communities cover approximately $9.4 \%$ of the earth's surface or $30 \%$ of the total land area" [7]. Most of these communities are belonging to marginalized, underprivileged and victims of structural injustice who retreated to the margins of society to preserve their culture [8]. They live in the forest, and are mostly affected by the changing forest conditions that climate variation may bring about [9] [10]. They take care of the forest environment because it is part of their living tradition. According to Igu [11] forests are vital "not only for the ecosystem and biogeochemical processes, but also for the livelihood of forest dependent communities for which its continual existence is a necessity." This assertion is supported by Hosunoma et al. [12] by saying that agriculture/livelihood related activities are the biggest drivers of forest denudation equivalent to $75 \%$ of human activities destroying the ecosystem. Having this gleam picture and the importance of forest ecosystem to human, animals, plants survival and the degree of devastation human activities may cause to the forest on a daily basis; there is a dire need for reforestation not only for ecological purpose but also for socioeconomic sustainability [13] [14].

\subsection{The Community Based Forest Management}

Community based forest management is one of the two prevailing forest management strategies the Philippine government employed and is characterized by active community participation in forest protection and resources governance. Mahanty et al. [15] defines community based forest management as "the governance and management of forest resources by communities, in collaboration with other stakeholders, for commercial purposes, subsistence, timber production, non timber forest products, wild life, conservation of biodiversity and en- 
vironment and for social and religious purpose". The underlying philosophy behind CBFM is the reality that people in the community are in the best position to solve local community forest problems. Given the chance to participate in decision making and forest conservation, the sustainability of the program and forest resources governance is ensured [16]. Strengthening this argument is the belief of Colchester when he said that sustainability of forest protection and management program depends to a great extent on the goodwill and participation of the community people.

Numerous researches proved that the success of forest management depends on community support. In Nepal, community participation in forest management led to the benefit of 1.7 million households and management of $1.2 \mathrm{hec}$ tares of forest lands [17]. Nigeria's experience revealed the importance of community coordination in the marketing of timber harvests creating thousands of jobs for the youth and benefiting thousands of households in terms of income and socio-economic support. In the same manner, the CBFM in Ngel Nyaki Forest Reserve is considered a game changer in forest protection and management where community participation reforested and restored a large size of denuded area and benefit thousands of volunteer groups. On the other parts of the globe, for instance in Mexico, Ghana and the USA their experiences pointed to the importance of factors for sustainability such as: tenurial arrangement in Ghana, which made the program successful; legal backing for the success of CBFM in Mexico; and the strong coordination and support of the Non Government Organization as conduit to government entity towards forest protection in the USA. The experiences in the NTUGI Hill Tharaca Nithi County in Africa on the one hand showed the importance of party integrity in the success of forest management. Nevertheless, despite diverse experiences in implementing CBFM in their countries, experiences proved the importance of tenurial arrangement, strong local institutions and massive local capacity building through institutional networking and linkages for the successful CBFM [18].

At present, researches in CBFM abound. However, the focus of many studies is on the analysis of the component technologies of the strategy. Many are impact evaluations of the implementation of CBFM on the national level. Only a few studies are written on the local level. In this regard, the study tried to describe the sustainability of CBFM in the municipality of Gabaldon, Nueva Ecija measured in terms of its impact to the preservation of Dupinga watershed. The study is significant to the community because its results would provide the bases for future community collaboration for community based forest resources protection. It will also serve as benchmark for possible community and multi sectoral collaboration to prevent continuing destruction of the area. The paper is also important to identify issues and concerns pertaining to watershed protection so that possible intervention may be done before it becomes too late.

Guided by the general principle that environmental awareness is the key to environmental protection [19], the following research objectives are framed. 


\subsection{Objectives of the Paper}

This paper has the general objective of evaluating the sustainability of existing stakeholders initiatives to protect Dupinga watershed in Gabaldon, Nueva Ecija, Philippines using the CBFM as theoretical framework.

Specifically, the study describe; 1) The evolution of CBFM model in the Philippines; 2) determine the sectoral-initiatives involved in preserving the Dupinga watershed; 3) identify issues and concerns related to the preservation of the $\mathrm{Du}$ pinga watershed; 4) and provide recommendations on how sustainability of $\mathrm{Du}$ pinga watershed may be made.

\section{Methodology}

\subsection{Data Gathering Technique}

The study used the descriptive analytic method using CBFM model as the frame of analysis. As a qualitative study, it inquires into the "how and why" of the forest management program in the study area in addition to documentary analysis [20] of the secondary data filed with the offices of the local government of Gabaldon, Nueva Ecija and the Department of Environment and Natural Resources were used to gather information on the initiatives of the different sectors to protect Mount Mingan the watershed area of Dupinga river. Interview with the natives of the place (Focus Group Discussion) was undertaken using open ended and free-willing discussion. Results of interview are reinforced by ocular inspection and actual observations. The qualitative-descriptive approach is used in the study as it may provide insights on the participatory forest management which may serve as inputs to local government units to implement rights based governance in the area of forest protection [21].

\subsection{Theoretical Framework/Legal Framework}

The theoretical framework for the study is hinged on the argument that Community Based Forest Management has direct and indirect benefits to the community and Dupinga Watershed. It is based on the assumption that protecting and preserving the forest ecosystem is preserving the Dupinga Watershed. The connection between the forest ecosystem and the watershed area is direct [22]. It further argued that the protection of the forest system may be analyzed using the Community Based Forest Management Model. Its components and processes could provide enough insights on the present and future sustainability of watershed areas.

The legal framework for sustainable forest management is well in placed. No other than the 1987 Philippine Constitution pronounces the duty of the State to "protect and promote the right to health of the people and instill health consciousness among them" [23]. The State also pronounces that "it is the duty of the State to protect and advance the right of the people to a balanced and healthful ecology in accord with the rhythm and harmony of nature" [24]. These state declarations engulf both the correlative duty of the State to promote and 
adopt measures to protect the forest ecosystem. Such protection is necessary for the enjoyment of present and future generations to come [25]. Such legal framework laid down the proper foundation not only for the State protection of forest resources but also the observance of sustainable forest management system. Finally to put into effect the constitutional provisions, it mandates that present generation Filipinos are stewards of the environment for the children of their children, thus, "to conserve and develop our patrimony and to secure to ourselves and our posterity the blessings of independence and democracy" [26].

It is worthy to note that the right of the people to a balanced ecology is directed for the benefit of communities living beside the forest ecosystem and most of them are Indigenous Peoples. The Constitution stresses out the right of Indigenous Peoples (IP) to ancestral domains and to resources within their territorial boundary subject to reasonable harvesting and sustainable practices [27]. Indigenous peoples consist of the majority of cultural communities living and depending on the environment. They are the people with indigenous knowledge and practices that evolved into the legal principle of ecological justice found on the pages of the 1987 Constitution [28]. Their contributions to climate change mitigation are proven sustainable but seldom documented and recognized. For instance, Indigenous women of Kalinga, Philippines and Cordillera upland communities have traditional practices and knowledge proven sustainable and effective in coping with the effects of climate variation [29]. The Calanguya tribe community's organizing for forest protection in Caraballo mountain in Luzon showed the sustainability of ecosystem management when community participation is solicited and the local folks are mobilized towards community actions.

The legal framework for CBFM is provided in numerous laws. All natural resources in public and private lands within the territory and exclusive economic zone of the Republic of the Philippines are owned by the state [30]. Since it is owned by the State, it is its responsibility to promote their rational exploration, development, utilization and conservation through the combined efforts of the governments and the private sector in order to enhance national growth in a way that effectively safeguard the environment and protect the rights of the affected communities [31]. Utilization of forest resources shall adhere to the principle of the sustainable development which meets the needs of the present generation without compromising the ability of the future generations to meet their own needs, with the view of improving the quality of life both now and in the future [32]. Thus the law requires that forest resources utilization, exploration, development and conservation should be pro-people and pro-environment in sustaining wealth creation and improved quality of life. Finally, the 1987 Philippine Constitution provides for the importance of cultural minorities in the pursuit of social justice and national development. Using as the guiding principle for national development the promotion of interests and protection of ancestral domains of Indigenous Peoples in all phases of national development efforts [33].

The CBFM as a strategy for forest protection took effect in 1995 by virtue of the Executive Order No.263 promulgated by Fidel V Ramos it unified all com- 
munity based forest protection program. The model grants the community legal access to occupy, possess, use and develop an area of up to more than 1000 ha of forest land. The organization is facilitated by NGO, PO and national Government Agency. The tenurial instruments created under the program are: Integrated Social Forestry Program, Certificate of Stewardship Contract (CSC) and Certificate of Ancestral Land Claim (CADC). In 2004 former President Gloria Macapagal-Arroyo issued another Executive Order reiterating the thrust of the government to recover forest resources thereby institutionalizing CBFM as the national strategy for forest protection and development. The CBFM is a forestry policy recognizing the need to involve communities in forest management. According to Professor Lasco and Pulhin, CBFM as theoretical framework and basis of sustainability has four main components, namely; 1) Natural forest management; 2) rehabilitation of degraded land 3) agro forestry; 4) biodiversity conservation including water resources conservation.

\subsection{Conceptual Framework}

From the afore cited theoretical framework the following conceptual framework guided the data gathering for the study:

As Figure 1 illustrates, the paradigm suggests Dupinga water shed is in the center of forest protection effort of the different sectors. It is not only because it provides source of clean water for agriculture and farmlands in the town of Gabaldon but also in the immediate vicinity of the Community Based Forest

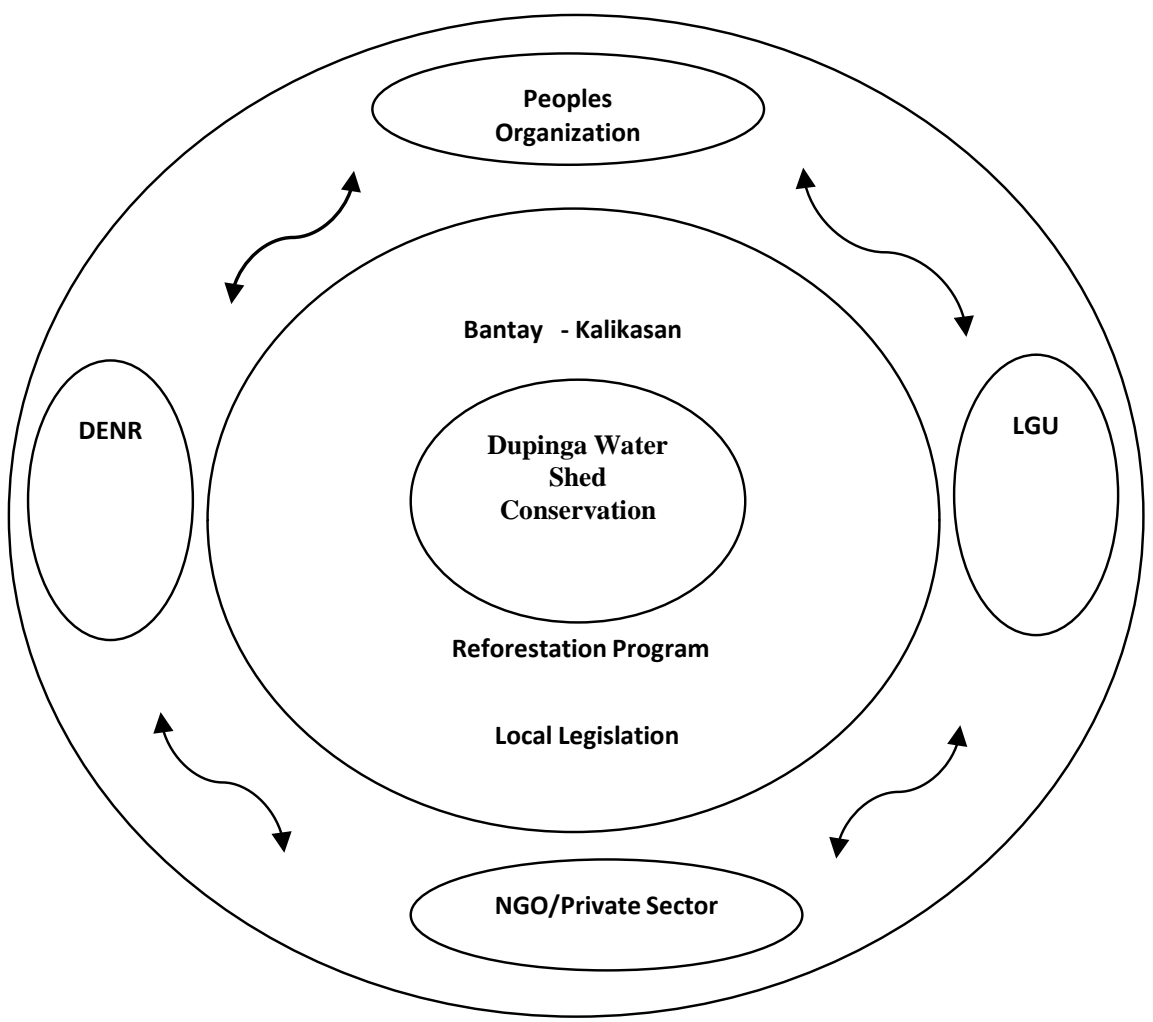

Figure 1. Community based forest management. 
Management. Figure 1 also shows in the outer circle the sectors collaborating to protect the watershed. Thus, the argument that protection of the forest is protection of the watershed area holds. Figure 1 also depicts the initiatives taken by the different sectors to ensure continues supply of high quality water not only for plants and animals but also for the tourists going into the Dupinga river. The arrow in Figure 1 depicts the coordination and linkages of the different entities to protect forest resources. At the outer layer of the figure are different sectors having the contribution to the multi-stakeholders forest protection.

\section{Results}

\subsection{Profile of Gabaldon Nueva Ecija}

The description and characteristics of Dupinga watershed can be gleaned from the data on filed with the Office of the Municipal Environmental Officer of Gabaldon Nueva Ecija, to wit:

The town of Gabaldon is measured 36,623 hectares. A former Sabani Estate and has a population of 32,426 as of 2010 . It is a third class municipality with a conglomeration of different ethnic groups namely: Tagalogs, Pampangueños, Ilocanos, Bicolanos, Visayans, Pangasinenses, and the indigenous community of Dumagats and others. It is located in Sierra Madre the largest mountain range in the Philippines. Gifted with God's bounties, it enjoys the presence of natural resources, timber, rattan, wildlife and minerals. It is one of the remotest municipalities in Nueva Ecija. It has sixteen (16) barangays: Bagting, Calabasa, Ligaya, Bagong Sikat, Tagumpay, Malinao, Pantoc, Macasandal, Camatchile, North Poblacion (leading barangay in paying taxes), South Poblacion, Bantug, Sawmill, Cuyapa and Pinamalisan.

\subsection{Characteristics of Dupinga Watershed}

Dupinga is chosen as the study area considering its critical condition. It is now losing its natural beauty and utility due to man-made pressure exerted on the watershed which go beyond its capacity. Education and awareness on the importance of the study site is necessary to save it from impending destruction. The Dupinga Watershed is located approximately between $15^{\circ} 28.3 \mathrm{~N}, 121^{\circ} 16.5 \mathrm{E}$, $15^{\circ} 37.2 \mathrm{~S}$ and $121^{\circ} 25.7 \mathrm{~W}$. It is situated between the two provinces of Nueva Ecija and Aurora. Although $81 \%$ of the watershed belongs to Aurora Province, access into the watershed is always through Gabaldon, the easternmost town of Nueva Ecija. This is the reason why the watershed is known to the people in the locality as within the territorial boundaries of the Municipality of Gabaldon. The Dupinga watershed covers an area of 14,470 hectares, which drains into the LaurGabaldon valley. The Dupinga River is a tributary of the Coronel River, which drains into the greater Pampanga River Basin.

The following vivid description of Dupinga watershed is found on file with the office of the Municipal Environment and Natural Resources and Environmental Research Division of the Manila Observatory (1993). Dupinga according to the municipal office," is composed of a series of un differentiated meta-volcanic and 
meta sedimentary rocks. These sedimentary rocks are well-bedded sandstones and silt stones, it has the same mineral assemblage and color of the meta volcanic rocks. Green schist, marbles, and meta sedimentary rocks are found along the Dupinga River to the confluence at Obsoan as well as to the western portion of Lingod area. In some areas, lime stones caps both schist and meta volcanic-meta sedimentary rocks can be found". Figure 2 below shows the location of the watershed.

The study area is illustrated as the research site 1 on Figure 2. Figure 2 is the best available document to identify the location of Dupinga watershed. The

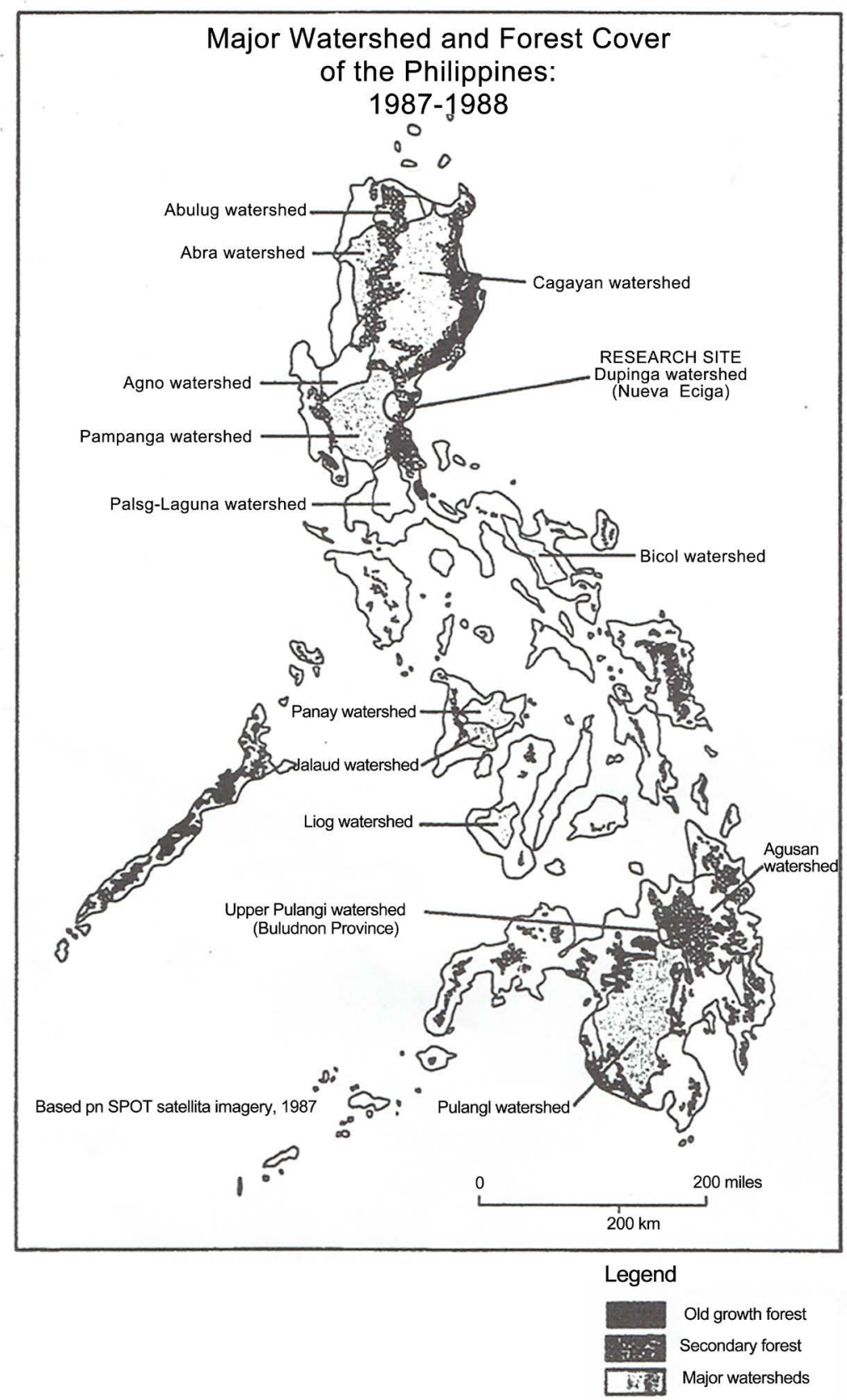

Figure 2. Location of Dupinga Watershed, Source: Environmental Research Division Manila Observatory. 
watershed shows $95 \%$ of the entire area in upland while only $5 \%$ is low land. The watershed is remarkably steep slopes, knife-edge ridges, sharp peaks, criss-crossed with minor faults giving rise to fragmented beds and steep slopes which are structurally weak. Moreover, the mine sites and road have and will only contribute to mass erosion of the area. Furthermore pressure on the watershed will lead to a hasten rate of erosion and sedimentation. Such condition in the study area can no longer be absorbed by the Laur-Gabaldon valley thus, it is very urgent and important that the watershed be preserved and protected so that further erosion and sedimentation can be retarded or prevented [34]. The Dupinga watershed is in critical condition.

The application of the study is the opportunity to learn from the Dupinga experiences in preserving the environment. The lessons learned from the Dupinga experiences may be replicated in some other water shed area in order to maintain its sustainability as the most logical solution to forest protection and management problem.

\subsection{Evolution of Community Based Forest Management in the Philippines}

Most of the discussion in the evolution of CBFM adopted the framework of Puhlin where the community forestry is divided into three phases. According to Puhlin, the year 1971-1980 was the period when the first participatory management strategy was implemented with some components of the present CBFM. It is coined as the Pioneering Phase. In this stage, the Forest Occupancy Management (FOM), Family Approach to Reforestation (FAR) and the Communal Tree Planting (CTP) were introduced as forestry strategies. These programs perceived the community as protector of forest resources and laborers to plant trees for reforestation purpose. The issue of communal ownership and rights over forest resources were not yet given emphasis. The root cause of the problem of deforestation was attributed to socio-political issues rather than socio-economic and property rights related to the power of the community to control forest resources distribution and management.

The second phase of CBFM development is toward participatory forestry management. It shifted the perception of community participation from laborers to resource managers

This is known as the Consolidation and Integration Phase which started in 1981 until late 1989. During this period, some of the property rights and distribution of forestry resources issues were integrated in the forestry program [35]. The Integrated Social Forestry was implemented and traced the roots of forest degradation from the socio-economic and political vantage points. Observable in this era was the presence of components intended to solve the problems of upland poverty alleviation, upland forest resources distribution and sustainable forestry. This is also the phase of CBFM development when community participation shifted to resource managers and financial supports of international funding agency, local and national government agencies form part of the program. In 
this era of implementation, the Integrated Forestry Program (ISFP) was implemented backed by technical and financial supports.

Finally, the Institutionalization and Expansion Phase of CBFM began in 1995, when President Fidel Valdez Ramos issued executive order number 263 adopting CBFM as the national strategy to ensure sustainable development of the existing forestland and its resources. Meanwhile in 2004, the then President Gloria Macapagal Arroyo issued Executive order No. 318 entitled "promoting sustainable forest management in the Philippines" while reiterating the need for the CBFM strategy to protect the forest resources. This period of implementation is characterized by the "drying up" of foreign funding assisting NGOs and PO's to perform their role within the framework of the CBFM. It is also the period when the role of the LGU in the protection of forest resources as one of its devolved functions [36], took place. Because of the devolutionary effect of RA7160 and the proximity of the LGU to forest community, CBFM coverage had tremendously increased. From the original less than 1 million hectare in 1995 to 5.97 million in 2010. The Philippine experience in CBFM also showed the vital role of NGO and GO in strengthening community forest management through strong coordination and inter agency linkages initiated by the Non Government Organizations (NGO) most especially during the period of transition from industrial forestry to Comprehensive Community Initiative (CCI) and recently, to Community Based Forest Management. According to Lasco and Pulhin forest management in CBFM projects is a strategy to arrest forest and watershed destruction and is composed of: natural forest management; rehabilitation of degraded lands and agro-forestry. The CBFM activities, as a government program, is expected to create environmental impacts such as 1) bio-diversity conservation; 2) soil conservation; 3) water resources conservation; 4) carbon sequestration; and 5) biomass production. As its program objectives, the CBFM is determined to achieve the goals of: 1) to ensuring the enjoyment of the people of their right to healthy ecology in accord with the rhythm and harmony of nature, 2) improving the socio-economic conditions of the Filipino people through the promotion of social justice, equitable access to and sustainable development of forest resources 3) respecting the rights of indigenous peoples to their ancestral domains. To realize its program objectives the CBFM has the following component strategies: 1) to build support institutions or groups to protect and promote resource based rights; 2) sustainable management of forest resources; 3 ) equity in distribution and access to forest benefits; 4) forging partnership with other institutions; 5) and establishing linkages for forest protection advocacy [37].

\section{Sustainability of Sectors' Initiatives in Watershed Protection in Gabaldon}

The implementation of CBFM can only be effective and sustainable if this will consider the peculiarities and environment of the locality. In the case of Gabaldon, the problems that multi stakeholders forest management tries to address are described as follows: 1) Deforestation, either cutting or burning of trees 
("kaingin") system, mining extraction, road construction and other developments that tend to reduce the tropical rainforest to about half their former size. And the decline in the biodiversity of the mountain range in the area. This decline will ultimately affect the ecological balance which would eventually result to less agricultural harvests, disease and adverse effects on the quality and sustainability of quality water in Dupinga watershed area.

\subsection{The Initiatives of LGU of Gabaldon Nueva Ecija, towards Sustainable Water Shed Management}

\section{Watershed}

The public views the watershed as an important life source of Gabaldon. The different sectors (POs, NGOs, private sectors) of the community participated to protect and preserve within their capabilities. It should be noted that for these sectors to effectively and efficiently participate in the watershed's preservation and protection initiatives enabling laws have to be formulated. In this context, CBFM recognized the important role of local government. As such, it is the primary duty of the Municipality to maintain the watershed's stability, as well as protect and preserve the said area. LGU-Gabaldon decisively responded to this challenge through the following:

1) Strict implementation of restoration and vegetation of the denuded portion of the area;

2) Awarding of Certificate of Land Ownership Agreement System to qualified beneficiaries of upland farmers for the proper management and utilization of the natural resources in the watershed;

3) Strict implementation of municipal ordinance prohibiting;

a) Illegal timber cutting (illegal logging);

b) Mining and other mineral extraction or operation;

c) Slash and burn or "kaingin" system;

d) Charcoal making;

e) Hunting of wildlife (endangered species);

f) Gathering rattan and other forest products;

4) Rehabilitation of old existing and construction of new roads.

\subsection{The Role of NGO, PO and Private Sector}

In 1986, the communities in the municipality of Gabaldon took a more direct approach to managing their watershed. Since 1990, Environmental Research Division (ERD) of Manila Observatory has been assisting these communities expand their understanding in their surroundings. A site analysis was undertaken focusing on the geophysical and socio-political aspects of the area. It suggested the need for a deeper multi-disciplinary research of the area.

The Community Forest Land Management Analysis Project (CFLMAP) for the Dupinga watershed in Gabaldon is an extension of this initial analysis. The objective is to explore the possibility of a rapid multi-disciplinary method in assessing a watershed's condition. By doing so, ERD would be in a better position to engage the community in formulating a management plan for the area. 
In 1990, the community of Gabaldon together with some members of the Alay Sambayanan sa Nueva Ecija Foundation (ANSEF) and the Social Action Foundation for Rural and Urban Development Inc. (SAFRUDI) requested the assistance of ERD in helping them understand changes taking place in their environment. It was agreed upon between ERD and a parish priest representing the community of Gabaldon, that ERD would do a site analysis of Gabaldon and its surrounding areas. In turn, the community would provide assistance to ERD for the duration of the site analysis. As the investigation precede, the support coming from the communities continued. Significantly, in the second half of the investigation, a local church based people's organization, Bantay ng Kalikasan Para Sa Kinabukasan ng mga Kabataan (BKKK), which was primarily set up to sustain community attention on the environmental problem, pledged for their support. The site analysis work was completed in 1991 and a report entitled "Coronel Watershed Report Gabaldon, Nueva Ecija" was released by ERD in October 1991.

The report, shared with the community, discuss the destructive physical processes in the area, such as erosion and flooding, and its relation to community activities. It also gave an account of community events that led to a greater awareness and more conscious action to protect the watershed. Furthermore, the report gave recommendations as preconditions for the development of a community-based watershed plan.

\subsubsection{Local Legislations}

In the implementation of CBFM and as issues and concerns were identified, LGU-Gabaldon has taken decisive steps in terms of local legislation. This strengthens mechanisms that will ensure that CBFM is given the local mandate and resources as it is being implemented.

In summary these legislations support the efforts done by other partners in CBFM implementation. These legislations were formulated to: stop illegal fishing; stop illegal hunting; stop illegal logging; control of slash and burn activities; Involving farmers in reforestation and adaptation of Environment Code of Gabaldon (still national in perspective but in the progress of localization).

\subsubsection{Livelihood Projects}

In the process of implementing CBFM, there is a need to identify efforts and projects to sustain initiatives already taken. Along this line, LGU-Gabaldon launched a municipal wide alternative livelihood programs in coordination with Japan International Cooperation Agency (JICA), DENR and Department of Agriculture for the enhancement of Community Based Forest Management. These projects aim to help divert or eliminate illegal forest activities like illegal cutting of trees and "kaingin" farming system. These livelihood activities are largely agriculture-based, thus utilizing whatever CBFM has gained in the process of its implementation.

1) Mushroom Culture Production.

2) Handmade Paper Making. 
3) Vermi-Composting.

4) Bamboo Handicraft Making.

5) Intercropping System.

6) Training on erosion prevention of riverbanks was also conducted as a mitigating measure to protect these areas.

7) Right granted by Department of Environment and Natural Resources to Nueva Ecija University of Science and technology to develop about 1,000 hectares of Mt. Mingan.

\subsection{Issues and Concerns}

The prospect of the area to become a tourist spot exerts pressure on the watershed carrying capacity. Dupinga is the cleanest inland body of water in the region and has been regional champion for the last three years. While it is not yet a problem, increasing tourism and vacationers in Dupinga will cause garbage problem in the river site. Environmental problems cause by tourism include the destruction of the environment as a result of construction of building or polluting the natural environment. Nevertheless, tourism is a sustainable alternative to forest destructive economic activities. Tourism if adapted to peculiar natural and human resources of the place may provide employment opportunities [38].

Being located in the longest mountain range in the country the wealth of Gabaldon's ecosystem diversity cannot be overlooked and allowed to be further endangered. Thus, ecosystem diversity must always be considered in the implementation of tourism as well as CBFM.

The less intense participation of the community in the multi stakeholders forest management would not warrant a sustainable program. It is observed that the program fails to gravitate into the community forest protection a sizeable number of community organizations. Thus local institutions building and management capacity is necessary to make the program sustainable. Some of the involved organization participated in the program as a form of "tokenism" [39]. They lack the persistence shown by a church based youth organization, Bantay Kalikasan para sa Kinabukasan ng mga Kabataan.

The prevailing slash and burn (Kaingin) system of farming remains an issue in the area. To stop the upland farmers from the practice of slash and burn without alternative livelihood support would make community participation difficult to solicit.

The issued logging licenses are still in use. The inability of the legal system to invalidate the efficacy of logging permits issued would greatly affect forest conservation and protection. The situation is further aggravated by the fact that concessionaires invested infrastructure like roads, bridges and structures in anticipation of their commercial timber activities making the action difficult to implement. This in the long run affects the integrity of the CBFM Program.

As the community of Gabaldon implements the CBFM, several issues and concerns were identified and need immediate attention so as to mitigate if not to stop their possible irreversible effects for the community and its biodiversity. 


\section{Summary Conclusion and Recommendations}

\subsection{Summary}

The Gabaldon experience of CBFM implementation is a work in progress and much still needs to be done. During the course of its implementation there were varied opportunities even hardships and disappointments. But these are all considered learning experiences where other communities can learn as they push forward in preserving and protecting their own forest for the future of the generations to come.

The study showed the importance of forest eco -system and the need for reforestation. The success of any effort towards forest protection is dependent on its sustainability. The legal framework has been established, but the study area is not fully protected from destruction and degradation arising from economic necessity of the community. The application of the CBFM model of forest conservation and protection is needed in the site to strengthen further the multisectoral collaboration taking place in the area and to prevent future destruction. Strengthening the social institution, collaboration of the local communities and capacity building programs must be sustained to ensure the watershed future preservation. Issues and concerns raised in the paper are reasonable and worth revisiting taking into consideration the prospect for local tourism of the research site. Finally, the Dupinga watershed is a natural environment and a lifeline for other animals, plants and human species. Its destruction would also put an end to the lives of the species dependent thereon, if not to human ecology and population.

\subsection{Conclusions}

The study showed the possibility of marshalling multi-sectoral resources and support towards the protection of water shed area. Though there is no existing CBFM Agreement in the study area, lessons may be derived from their experiences.

1) The participation of the community is ensured and made sustainable when the different sectors are sufficiently informed and made to participate in the various stages of implementation. Capacity building, institutional strengthening and network linkages are common to countries who experienced successful implementation of CBFM e.g. Africa, Mexico, USA and Nigeria.

2) Commitment of the POs and NGOs even the Indigenous Peoples and the private sector is critical in the long-term. Genuine community participation in the implementation of CBFM and in preserving what has been achieved is crucial. The vast forest area cannot be monitored and safeguarded without sizeable personnel complement and financial resources which the government cannot provide. Community participation in forest protection is a better alternative and is more sustainable.

3) The role of LGU-Gabaldon is vital in putting together and organizing the wide-range of efforts into a cohesive, effective and efficient response to the vari- 
ous aspects of forest management. The Gabaldon experience teaches us that the participation of the local government provides sustainability to whatever efforts and achievements that were already attained through relevant local legislations and support to livelihood projects.

4) The supports of NGAs ensure that efforts and programs undertaken by the community are within the national and regional frameworks. In this regard local institutions and initiatives must be strengthened and the State must divest some of its traditional control of forest lands in favor of local community [40].

\subsection{Recommendations}

As the multi-sectoral engagement continues in Gabaldon in the effort to implement CBFM, there are several recommendations that are identified to further enhance the present initiatives. Briefly, these recommendations are:

Protection and conservation of lowland forest. This forest type is considered the most threatened forest ecosystem in the country. Most of the lowland forest in the country today has already been dissipated mainly due to logging in the past and the continuous landscape modification due to rapid human expansion of agriculture. The protection of the remaining lowland forest in Mount Mingan should be an urgent priority of the Local Government Units and the Department of Environment and Natural Resources.

Establish and identify protected area (key biodiversity area) [41]. One of the most effective approaches in the conservation of biological resources is the creation of a protected area. This approach ensures that the management of the Mount Mingan and its resources is not a sole responsibility of the DENR and the Local Government Units (LGU) involved but also of the people living in the lower portion of the mountain. Use of indigenous planting materials for reforestation and restoration indicative within the area should also be encouraged to help maintain the integrity of native flora.

Alternative livelihood programs. Poverty in the rural areas has always been one of the driving factors of local community to access the abundant forest resources and its rich souls. By providing them with the appropriate tools and teaching them the best farming practices/techniques (such as agro-forestry) it can help local people maximize the use of their land and increase their income.

Regular and further biological surveys. The rate of species discovery and the backlog in biological fieldwork, as exemplified in our study, underscores an indication that an enormous work, both taxonomic and explorative, is still needed in the Philippines. Research focus on the status, factors that limit their population, ecology and behavior of threatened and frequently hunted species are also needed to prevent further extirpation of these animals. Knowledge about biodiversity can help provide our decision makers the necessary data to formulate sound management decisions and plans.

The participation of Nueva Ecija University of Science and Technology and its Gabaldon Campus to CBFM will be a welcome development. The university's vast resources and unwavering support to environmental protection and sus- 
tainable development as manifested by the construction of a micro-hydro electric power plant and the establishment of a Research Center in Agriculture and Forestry that could boost and sustain efforts towards forest protection and preservation of Dupinga watershed in Gabaldon, Nueva Ecija, Philippines.

\section{Acknowledgements}

Our gratitude to the former Municipal Mayor of Gabaldon, Nueva Ecija, Dominador Mandia and to our Graduate School students from the Department of Environment and Natural Resources, Nueva Ecija, Philippines; (Linda, Leonard, Tin Tin and Cristina). Many thanks to the Vice President for Academic Affairs of the University Feliciano A. Bolisay for the administrative support extended to the researchers.

\section{References}

[1] The Scientific American (Undated) Measuring the Daily Destruction of the World's Rain Forests. https://www.scientificAmerican.com/article/earth-talks-daily-destruction/

[2] Cruz, F. and Acay, F. (2004) People's Organization Attributes and Institutional Viability of Selected Community Based Forest Management Environmental Education Network of the Philippines Inc. UPLB College Laguna.

[3] Oposa vs Factoran (1993) GR No. 101083. http://www.lawphil.net/judjuris/juri1993/

[4] Keong, C.Y. (2015) Sustainable Resource Management and Ecological Conservation of Mega-Biodiversity: The Southeast Asian Big-3 Reality. International Journal of Environmental Science and Development, 6. http://www.ijesd.org/vol6/715-C0009.pdf

[5] Borokini T.I., et al. (2012) Community Based Forest Resources Management in Nigeria: Case Study of of Ngel Nyaki Forest Reserve, Mambilla Plateau, Taraba State, Nigeria. Journal of Tropical Forestry and Environment, 2, 69-76. https://www.researchgate.net/publication/264850777_Community-based_Forest_Re sources_Management_in_Nigeria_Case_study_of_Ngel_Nyaki_Forest_Reserve_Ma mbilla_Plateau_Ta

[6] Upadhyay Shrikrishna (2017) Community Based Forest and Livelihood Management in Nepal.

http://wealthofthecommons.org/essay/community-based-forest-and-livelihood-ma nagement-nepal

[7] Naganag, E.M. (2014) The Role of Indigenous Women in Forest Conservation in Upland Kalinga Province, Northern Philippines. http://www.garp.co.uk/IJARMSS/June2014/8.pdf

[8] Gabriel, A.G. (2013) "Indigenous Peoples Perceptions on Domestic Violence": The Case of Dumagat Tribe. Rurban Journal, 4, 56-67.

[9] Salick J. and Byg, A. (2007) Indigenous People and Climate Change. University of Oxford and Missouri Botanical Garden, Oxford. http://tyndall.ac.uk/sites/default/files/Indigenous\%20Peoples\%20and\%20Climate\% 20Change_0.pdf

[10] Ban, K.-M. (2007) United Nations Permanent Forum Indigenous Issues. Climate Change and Indigenous Peoples.

http://www.un.org/en/events/indigenousday/pdf/Backgrounder_ClimateChange_FI 
NAL.pdf

[11] Igu, N.I. (2017) Swamp Forest Use and Loss in the Niger Delta: Contextual and Underlying Issues. Open Journal of Forestry, 7, 34-37.

https://doi.org/10.4236/ojf.2017.71003

[12] Hosunoma, N., et al. (2012) An Assessment of Deforestation and Forest Degradation Drivers in Developing Countries. Environmental Research Letter, 7, Article ID: 044009. http://iopscience.iop.org/article/10.1088/1748-9326/7/4/044009/meta

[13] Lasco, R.D. and Pulhin, J.M. (2006) Environmental Environmental Impacts of Community-Based Forest Management in the Philippines. International Journal of Environment and Sustainable Development, 5, 46-56. https://doi.org/10.1504/IJESD.2006.008682

[14] Guiang, E.S., Borlagdan, S.B. and Pulhi, J. (2001) Community-Based Forest Management in the Philippines: A Preliminary Assessment.

http://dlc.dlib.indiana.edu/dlc/bitstream/handle/10535/7541/CBFM\%20Preliminary \%20Assessment.pdf? sequence $=1$

[15] Mahanty, S., Gronow, J., Nurse, M. and Malla, Y. (2006) Reducing Poverty through Community Based Forest Management in Asia. Journal of Forest and Livelihood, 5, 78-89.

[16] Duthy, S. and Duthy, B. (2003) Peoples Organization in Community Forest Based Management. Annals of Tropical Research, 2592, 13-27.

[17] Karithi Matti, E. (2014) Community Participation in Forest Management: A Case Study of Ntugi Hill Thraka Nithi County.

[18] Wood, L. (2008) Community Based Natural Resource Management: Case Studies from Forest Management Projects in Ghana, Mexico, and United States of America.

[19] Ghobadi, G.J. and Verdan, M.S. (2016) The Environmental Effects of Tourism Development in NOUSHAR. Open Journal of Ecology, 6, 529-536.

https://doi.org/10.4236/oje.2016.69050

[20] Ariola Mariano, M. (2006) Principles and Methods of Research. Rex Bookstore Inc., Sampaloc.

[21] Chauhan, A.M. (2005) Quantitative and Qualitative Approaches to Measuring Indigenous Peoples Rights. Commission on Human Rights.

http://www.tebtebba.org/index.php/allresources/category/116-presentations?...dow $\underline{\text { nload }=6.25 \text { measuring-indigenouspeoples-rights-in-the-philippines-themetagora-p }}$ eoplesrights-in-the-philippinesthemetagoraexperience

[22] Lasco, R.D. and Pulhin, J.M. (2006) Environmental Environmental Impacts of Community-Based Forest Management in the Philippines. International Journal of Environment and Sustainable Development, 5, 46-56. https://doi.org/10.1504/IJESD.2006.008682

[23] Article II, Section 15 of the Philippine Constitution.

[24] Article II, Section 16 of the Philippine Constitution.

[25] De Leon, H. (2007) The 1987 Philippine Constitution. Rex Bookstore Metro, Manila.

[26] Preamble. The 1987 Philippine Constitution.

[27] Republic Act 8371. An Act to Recognize, Protect and Promote the Rights of Indigenous Cultural Communities /Indigenous Peoples Creating a National Commission on Indigenous Peoples, Establishing Implanting Mechanisms Appropriating Funds Therefore and for Other Purposes in Official Gazzette of the Republic of the Philippines. www.gov.ph?1997/10/29/republicact-no8371/

[28] Agabin, P.A. (2011) The Influence of Indigenous Law in the Development of New Concept of Social Justice. IBP Journal, 36, 1-18. 
[29] Gabriel, A.G. and Mangahas, T.L.S. (2017) Indigenous People's Contribution to the Mitagation of Climate Variation Their Perception, and Organziing Startegy for Sustainable Community Based Forest Resources Management in Caraballo Mountain, Philippines. Open Journal of Ecology, 7, 85-100. https://doi.org/10.4236/oje.2017.72007

[30] Article XII, Section 2 of the Philippine Constitution.

[31] Republic Act No. 8371, Section 5.

[32] World Commission on Environmental Development (1987). www.wsu.edu/ susdev/WCED87.html

[33] Article II, Section 10.

[34] ERD (1990) Environmental Research Division of the Manila Observatory.

[35] Harisson S.R., Emtage F.N. and Nasayao, B.E. (Undated) Past and Present Support Programs in the Philippines Small Scale Forest Economics. Management and Policy, 3, 303-317.

[36] Republic Act No. 7160. An Act Providing for a Local Government Code of 1991. http://www.gov.ph/1991/10/10/republic-act-no-7160/

[37] Colchester Marcus (1992) Sustaining the Forest: The Community Based Approach in South-East Asia. World Commission on Environment and Development United Nations Research Institute for Social Development.

[38] Shamsoddini, A. (2015) Evaluation of Tourism Status in Sustainable Rural Development by Reynard Model. Open Journal of Ecology, 5, 80-85. https://doi.org/10.4236/oje.2015.53008

[39] Arnstein, S. (1969) A Ladder of Community Participation. Journal of the American Institute of Planners, 35, 216-224.

http://lithgow-schmidt.dk/sherry-arnstein/ladder-of-citizen-participation.html https://doi.org/10.1080/01944366908977225

[40] Poteete, A. and Ribot, J. (2009) Repertoires of Domination in Decentralization: Cases from Botswana and Senegal. Working Group Papers on Politics on Authority, Land and Natural Resources, Indianan University, Bloomington.

[41] Gabaldon Environment Code: Municipal Ordinance No. 52 Series of 2008. A Resolution Endorsing the Inclusion of Dupinga Watershed to the Proposed Aurora Memorial National Park (AMNP) under the Sierra Madre Biodiversity Corridor Program: Resolution No. 45 Series of 2002.

Scientific Research Publishing

\section{Submit or recommend next manuscript to SCIRP and we will provide best service for you:}

Accepting pre-submission inquiries through Email, Facebook, LinkedIn, Twitter, etc. A wide selection of journals (inclusive of 9 subjects, more than 200 journals)

Providing 24-hour high-quality service

User-friendly online submission system

Fair and swift peer-review system

Efficient typesetting and proofreading procedure

Display of the result of downloads and visits, as well as the number of cited articles

Maximum dissemination of your research work

Submit your manuscript at: http://papersubmission.scirp.org/

Or contact oje@scirp.org 